\title{
EXOGYRA OLISIPONENSIS SHARPE AND EXOGYRA COSTATA SAY IN THE CRETACEOUS OF THE WESTERN INTERIOR
}

\author{
By John B. Reeside, Jr.
}

\section{INTRODUCTION}

This paper records the occurrence in the Upper Cretaceous of the Western Interior of Exogyra olisiponensis Sharpe, not hitherto noted in the United States, and of Exogyra costata Say, not previously known outside of the Atlantic and Gulf coastal region. Notes on the genus and both species are included, and representative specimens are figures.

\section{GENUS EXOGYRA}

The genus Exogyra has been discussed at length by many writers since its establishment in 1820 by Say. ${ }^{1}$ Among the later descriptions that of Pervinquière ${ }^{2}$ is particularly useful for Cretaceous species. The extensive treatise of Jourdy ${ }^{3}$ is the most comprehensive general discussion and affords a compact history of the vicissitudes the genus has undergone since its establishment, a statement of its present scope, range, and other details of highest interest to the student of Exogyra. No better characterization is available than that given by Jourdy, ${ }^{4}$ which may be translated as follows:

General form.-Arcuate, in a sort of crescent in the narrow, elongated species. The oldest species are unornamented, small, even dwarfed; the later species are often large and ornamented to various degrees.

Upper (right) valve.-Generally flat, thin, operculiform, marked by concentric growth lines disposed in spirals whose center is at the beak, placed at the posterior summit of the shell. Sometimes radial ribs, rarely tubercles.

Lower (left) valve.-Deep, carinate, and with helicoid beak in proportion as the area of attachment is less extended; absolutely flat in the case of maximum area of attachment. Sometimes winglike expansions beneath the hinge. The ornamentation consists of concentric striae, more or less lamellose, or of radial ribs, more or less fine, rarely tuberculated or spinose.

Hinge. - The hinge of the lower valve, in youth and in small species, reduced to a ligamental groove, twisted and without thickened lateral ridges; that of heavier species is at first anodont but becomes monodont in the most differentiated species, the latter arrangement characterized by a blunt tooth in the upper valve corresponding to a shallow groove or dimple in the lower valve.

As understood by the above characterization, Exogyra ranges from the upper Liassic (Toarcian) to the end of the Cretaceous and possibly into the Tertiary, changing, in general, from small, rather flattened, unsculptured species to large, deep-shelled, sculptured species.

1 Say, Thomas, Observations on some species of zoophytes, shells, etc., principally fossil: Am. Jour. Sci., vol. 2, p. 43, 1820.

- Pervinquière, Lón, Études de paleontologie tunisienne, pt. 2, Gastropodes et lamellibranches des terrains crótacés, pp. 172-193, Paris, 1912.

8 Jourdy, Edmond, Histoire uaturelle des Exogyres: Annales de paleontologie, vol. 13 , pts. $1,2,1924$.

- Idem, p. 97.

$100874^{\circ}-29-18$
Pervinquière, ${ }^{5}$ dealing chiefly with Cretaceous forms, divided Exogyra into groups whose limits, he says, "are often difficult to define" and which are possibly to be viewed as subgenera. These groups are:

1. Group of E. costata Say.

2. Group of $E$. latissima Lamarck (couloni-aquila) ( $=$ Aetostreon Bayle).

3. Group of $E$. columba Lamarck (=Rhynchostreon Bayle).

4. Group of $E$. africana Coquand.

5. Group of $E$. haliotidea Sowerby.

6. Group of E. flabellata Goldfuss (=Ceratostreon Bayle).

Jourdy ${ }^{6}$ considered Pervinquière's grouping not sufficiently comprehensive and lacking the phylogenetic viewpoint and proposed another, as follows:

A. Gibbous and smooth line derived from E. monoptera Deslongchamps; several species show a suggestion of excrescences, $E$. arduennensis D'Orbigny, $E$. larteti Coquand.

B. Shallow, smooth line derived from $E$. lingulata (Walton) Lycett, continued by $E$. rauliniana D'Orbigny, $E$. haliotidea Sowerby, E. bourgeoisi Coquand, E. auricularis Goldfuss.

C. Smooth line carried to the end of the Jurassic by $E$. nana Sowerby and branching in the Cretaceous into two lines: $\mathrm{C}_{1}$. An entirely unsculptured line including $E$. tombeckiana D'Orbigny; large forms like $E$. aquila Goldfuss; $E$. conica Sowerby; $E$. langloisi Coquand; a few forms inclined to become spinose, $E$. couloni Defrance, $E$. plicifera Dujardin.

$\mathrm{C}_{2}$. A lamellose line apparently beginning with $E$. polygona Von Buch, continued by $E$. africana Lamarck, $E$. deletrei Coquand, E. subfimbriata Coquand, etc. Through E. ponderosa Roemer it produced $E$. costata Say, and through other lamel-. lose forms, $E$. overwegi Von Buch, $E$. texana Roemer, ${ }^{7}$ E. fourneti Coquand.

D. Sculptured Jurassic line, derived from the line of $E$. nana through $E$. praevirgula Douville and Jourdy, the source of the ornate species which are the most numerous and most beautiful of the genus. There are two lines:

$D_{1}$. Line of $E$. virgula Defrance, with very fine, regular costation, including $E$. larteti Coquand, $E$. suborbiculata Lamarck, $E$. decussata Goldfuss, $E$. columba Lamarck.

$\mathrm{D}_{2}$. Line of $E$. catalonica Loriol with strong ribs, derived from $E$. virgula through $E$. welschi Jourdy. It reaches the Cretaceous through $E$. minos Coquand and continues by $E$. callimorphe Coquand, $E$. boussingaulti D'Orbigny, $E$. harpa Forbes, $E$. olisiponensis Sharpe, $E$. flabellata Goldfuss, $\boldsymbol{E}$. matheroniana D'Orbigny, $E$. laciniata Nilsson, $E$. lemeslei Jourdy.

s Pervinquière, Léon, op. cit., p. 172

B Jourdy, Edmond, op. cit., p. 91.

7 E. texana has been placed by many authors under $E$. flabellata and surely belongs to the same group. Jourdy must have placed the species here by error instead of in the group $\mathrm{D}_{\text {? }}$ 
Jourdy notes the lack of important variations in the sculpture of the upper (right) valve. It shows from the earliest species the well-defined spiral trace of the beak and only in a few species any but conoentric sculpture. The helix of the beak of the lower (left) valve also enters but little into the evolution of either genus or species. The very earliest forms are so strongly attached that they do not show a helix, though it is present in the oldest forms of $E$. nana (Callovian). Slender beaks are the more numerous and persist almost to the end of the Cretaceous, though the best-developed helices appear in the Upper Cretaceous. In a general way the forms that end the several genetic lines have the best development of dentate hinge, ornamented surface, and helicoid beaks, and there is a progression from simpler early types to more complex later types.

\section{Exogyra olisiponensis Sharpe}

Plates 65-68; Plate 69, Figures 1-4:

1850. Exogyra olisiponensis Sharpe, Geol. Soc. London Quart. Jour., vol. 6, p. 185, pl. 19, figs, 1, 2.

1862. Ostrea overwegi Coquand (not Von Buch), Soc. émulation Provence Mém., vol. 2, p. 226, pl. 19, figs. 1-6.

1862. Ostrea coquandi Julien. Coquand, op. cit., p. 324, pl. 33, figs. $10-12$.

1864. Ostrea (Exogyra) cornuarietis Meneghini (not Goldfuss), Soc. ital. sci. nat. Atti, vol. 6, p. 412, pl. 4, figs. 1 a-c.

1869. Ostrea olisiponensis Sharpe. Coquand, Monographie du genre Ostrea, terrain crétacé, p. 125, pl. 45, figs. 1-7.

1869. Ostrea overwegi Coquand (not Von Buch), op. cit., p. 140, pl. 44, figs, 1-7 (8-9?); pl. 46, figs. 14-15.

1872. Ostrea olisiponensis Sharpe. Lartet, Annales sci. géol., vol. 3 , p. 59 , pl. 11, figs. 1-2.

1875. Exogyra ponderosa White (not Roemer), U. S. Geog. Surveys W. 100th Mer Rept., vol. 4, pt. 1, p. 172, pl. 14, figs. 1 a-c.

1877. Ostrea olisiponensis Sharpe. Lartet, Exploration géologique de la Mer Morte, p. 138, pl. 9, figs. 1-3.

1880. Ostrea oxyntas Coquand, Acad. Hippone Bull. 15, p. 170.

1882. Exogyra oxyntas Coquand. Seguenza, R. accad. Lincei Atti, ser. 13, vol. 12, p. 178, pl. 18, figs. 1 a-c.

1882. Exogyra olisoponensis Sharpe. Seguenza, op. cit., p. 180. pl. 17, figs. 2 a-b.

1886. Exogyra pseudoafricana (part) Choffat, Faune crétacique du Portugal, vol. 1, ser. 1, p. 38 (not Ostreidae, pl. 4, figs. 1-4); ser. 4, Ostreidae, pl. 6, fig. 14 [1902].

1891. Ostrea olisiponensis Sharpe. Peron, Exploration scientifique de la Tunisie, pt. 4, Invertébrés fossiles des terrains crétacés, p. 114, pl. 23, figs. 14-18.

1902. Ostrea (Exogyra) olisiponensis Sharpe. Choffat, Faune crétacique du Portugal, vol. 1, ser. 4, p. 166, Ostreidae, pl. 6, figs. 17-19.

1903. Exogyra olisiponensis Sharpe. Fourtau, Inst. égyptien Bull., ser. 4, vol. 4, p. 283, text figs. 3-5.

1903. Exogyra olisiponensis Sharpe var. duplex, Paulcke, Neues Jahrb., Beilage-Band 17, p. 269, pl. 15, figs. 7, 8.

1905. Ostrea (Exogyra) olisiponensis Sharpe. Choffat, Contributions à la connaissance géologique des colonies portugaises d'Afrique, pt. 2, Nouvelles données sur la zone littorale d'Angola, p. 44, pl. 1, figs. 4, 5 .

1911. Ostrea (Exogyra) olisiponensis Sharpe. Woods, in Falconer, The geology and geography of northern Nigeria, app. 2, p. 277 , pl. 20 , figs. 1-3.
1912. Exogyra olisiponensis Sharpe. Pervinquière, Études de paléontologie turisienne, pt. 2, Gastropodes et lamellibranches des terrains crétacés, p. 174, pl. 13, figs. 4, 5, 9 .

1918. Exogyra olisiponensis Sharpe? Böse, Texas Univ. Bull. 1856 , p. 230 , pl. 20 , fig. 4.

1927. Exogyra olisiponensis Sharpe. Reeside, in Wasson and Sinclair, Am. Assoc. Petroleum Geologists Bull., vol. 11, p. 1268, pl. 11, figs. 1-3.

Sharpe's original description of the species, based on material from the "Hippurite limestone" at Lisbon, Portugal, is as follows:

Shell nearly hemispherical; upper valve thick, slightly gibbose, covered with regularly concentric scales, the beak incurved in the plane of the valve; lower valve very thick and very gibbose, regularly rounded on the anterior margin and somewhat produced posteriorly; the surface squamose, with the edges of the scales raised up into short ribs, of which there are 10 or 12 near the margin of an old shell; in some specimens the ribs are nearly continuous; in others they only occur near the margin of the scales, while in others they are hardly visible; the surface of the valve between the ribs is nearly smooth; beak of the lower valve laterally involute; the surface of attachment usually small.

Coquand in his earlier work ${ }^{8}$ assigned to $E$. olisiponensis only distantly ribbed, somewhat spinose, keeled shells, assigning to $E$. overwegi Von Buch the finer-ribbed, rather evenly sculptured, well-rounded forms. Under $E$. overwegi he distinguished five varieties-costulata, scabra, rugosa, reticulata, and laevigata. Coquand later $^{9}$ noted that the real $E$. overwegi was a different and much later type and renamed his material $E$. oxyntas. Coquand cited E. olisiponensis from southern France, Spain, Portugal, Algeria, and Palestine. He cited his E. overwegi (=oxyntas) from Sicily, Tripoli, Tunisia, Palestine, southern France, and Spain.

Meneghini ${ }^{10}$ assigned to $E$. cornuarietis Goldfuss nearly smooth forms of $E$. olisiponensis from Sicily.

Lartet ${ }^{11}$ followed Coquand in his use of the names $E$. overwegi and $E$. olisiponensis as applied to specimens from Palestine, putting the relatively fine-ribbed forms into the first and the more coarsely ribbed forms into the second species.

Seguenza ${ }^{12}$ also followed Coquand in distinguishing $E$. olisiponensis from $E$. oxyntas. Under $E$. olisiponensis he named three varieties-the typical form, var. ecostata, 'and var. prominens. Under E. oxyntas he accepted Coquand's five varieties and added four more-ecostata, italica, asperrima, and brancaleonensis.

8 Coquand, Henri, Géologie et paléontologie de la région sud de la province de Constantine: Soc. émulation Provence Mém., vol. 2 , p. 226 , pl. 19, figs. $1-6,1862$ Monographie du genre Ostrea, terrain crétacé, pp. 125, 140, pl. 44, figs. 1-7; pl. 45, figs. 1-7, Marseille, 1869.

${ }^{\theta}$ Coquand, Henri, Études supplémentaires sur la paleontologie algérienne: Acad. Hippone Bull. 15, p. 170, 1880

${ }^{10}$ Meneghini, Giuseppe, Studii paleontologici sulle ostriche cretacee di Sicilia: Soc. ital. sci. nat. Atti, vol. 6, p. 412, pl. 4, figs. 1 a-c, 1864.

11 Lartet, Louis, Essai sur la géologie de la Palestine: Annales sci. géol., vol. 3, p. 59 , pl. 11 , figs. $1-2,1872$

12 Seguenza, Giuseppe, Studi geologici e paleontologici sul cretaceo medio dell, Italia meridionale: R. accad. Eincei Atti, ser. 3, vol. 12, pp. 178-180, pl. 17, figs. 2-2b; pl. 18 , figs. 1-1c, 1882. 
The variety brancaleonensis, so far as one may judge from figures, has the broad rounded ribs of the costata group rather than the narrow ribs of the earlier group to which E. olisiponensis belongs. Seguenza's specimens came from Sicily.

Choffat ${ }^{13}$ seems to have included in his $E$. pseudoafricana feebly costate shells that belong to $E$. olisiponensis, believing that the second species were derived from the first. Choffat also called attention to the radial ribs on the upper valves of many individuals of $E$. olisiponensis, a feature that had escaped record by the previous students of the species.

Peron ${ }^{14}$ united E. oxyntas and parts of certain other species, as conceived by Coquand, with $E$. olisiponensis. He showed that the presence of a keel on the shell is a very variable feature: in Sharpe's type its prominence is accidental and due to the large size of the area of attachment, and it is not the important character which Coquand thought it to be. Peron noted the great range of variability in size, form, and both concentric and radial sculpture that may be met in a large collection and was inclined to consider $E$. pseudoafricana Choffat as belonging to $E$. olisiponensis and also part of E. trigeri Coquand. Peron dealt with material from Tunisia and assigned it to the Cenomanian.

Choffat ${ }^{15}$ in a later paper did not accept Peron's assimilation of $E$. oxyntas and $E$. olisiponensis. $\mathrm{He}$ also recanted his earlier opinion of relationship between E. pseudoafricana and E. olisiponensis and gave the range of $E$. olisiponensis as from upper Cenomanian to upper Turonian, assigning the type locality to the upper Turonian. On the basis of about 100 specimens from the type locality (Alcantara, near Lisbon, Portugal), he gave an emended diagnosis of the species which may be translated as follows:

Shell inequivalve, higher than wide in youth; in adult age the dimensions are equal, or the width is greater than the height. Outline oval or subcircular, anterior border rectilinear, forming generally a rounded angle with the pallial border.

Upper valve oval, thick, lightly and irregularly convex, with beak recurved in the plane of the shell, smooth or nearly smooth in the earliest stages, then acquiring growth lamellae that are vertical, sharp, crowded closely together, bifurcating and uniting again in a short distance. Besides the concentric lamellae there are radial swellings irregular, generally narrow, raised (as much as 3 millimeters), hardly any wider at base than at summit; they are irregularly spaced and seem sometimes to bifurcate. They rarely appear at a diameter of 10 millimeters, but generally at that of 20 millimeters, but I know only two specimens in which they appear as late as in the specimen figured by Sharpe. Their number ranges from 7 to 12 .

Lower valve very thick, very gibbous, the anterior third more or less flattened and the rest of the shell regularly rounded with beak generally more or less flattened, as in Sharpe's figure and in my Figure 19; very rarely free, as in my Figure 17.

18 Choffat, Paul, Faune crétacique du Portugal, vol. 1, ser. 1, p. 38, 1886; vol. 1 ser. 4, Ostreidao, pl. 6, fig. 14, 1902.

11 Peron, Alphonse, Exploration scientifque de la Tunisie, pt. 4, Invertébrés fossiles des terrains crétacés de la région sud des hauts plateaux de la Tunisie, pp. 114-119, pl. 23, figs. 14-18, Paris, 1891.

${ }^{16}$ Choffat, Paul, Faune crôtacique du Portugal, vol. 1, ser. 4, p. 166, Ostreidae, pl. 6 , figs. 17-19, 1902.
Scar of attachment generally small. The exterior surface is ornamented by growth lamellae, often raised along radial lines, forming sometimes continuous ribs, lamellose, spinose when well preserved, more or less widely spaced, reaching to the beak when attachment does not prevent. Some disappear before reaching the pallial border; others appear on the middle of the shell. Their distance apart and consequently their number is variable; the original of Sharpe and that of my Figure 17 may be considered to have distant ribs, but others have them much nearer. Ligamental groove deep in young individuals and shallow in the older ones. Muscular impression of medium size, near the anterior border.

Paulcke ${ }^{16}$ described from Peru E. olisiponensis var. duplex, founding it on shells with a broad furrow extending from the beak on the posterior side of the lower valve and especially strong radial ribs on the upper valve extending almost from the beak instead of leaving a central area smooth or with only concentric sculpture. With this variety he said he found the typical form of the species.

Fourtau ${ }^{17}$ included under $E$. olisiponensis $E$. oxyntas and $E$. pseudoafricana, believing that he had them all together in the Cenomanian of Egypt.

Choffat ${ }^{18}$ described from Angola typical E. olisiponensis and reiterated his stand of 1902 that $E$. pseudoafricana is distinct.

Schlagintweit ${ }^{19}$ recorded E. olisiponensis from Peru, suggesting that possibly $E$. polygona Von Buch as figured by Von Buch and Gabb is to be considered identical with $E$.olisiponensis, though he allowed the question to remain open until the originals could be compared.

Woods ${ }^{20}$ described from Nigeria specimens of $E$. olisiponensis marked by only a few radial ribs. Woods considered the two Nigerian localities as Turonian, though only one furnished associated species.

Pervinquière ${ }^{21}$ described from the middle and upper Cenomanian of Tunisia both typical and varietal forms of $E$. olisiponensis. He united with it $E$. oxyntas Coquand and part of E. pseudoafricana Choffat. Pervinquière mentioned six variants (see p. 270), though he saw no advantage in naming them. He believed E. olisiponensis to be exclusively Cenomanian.

Böse ${ }^{22}$ reported from Coahuila, Mexico, a single specimen which he referred with doubt to E. olisiponensis and to the Cenomanian. It is not well preserved but seems to the writer, so far as the figure may indicate, to belong to the species.

16 Paulcke, Wilhelm, Ueber die Kreideformation in Südamerika und ihre Beziehungen zu anderen Gebieten: Neues Jahrb., Beilage-Band 17, p. 269, pl. 15, figs. 7, 8, 1903.

${ }^{17}$ Fourtau, R., Contribution a l'étude de la faune crétacique d'Égypte: Inst. Égyptien Bull., ser. 4, vol. 4, p. 283, text figs. 3-5, 1903.

18 Choffat, Paul, Contributions a la connaissance géologique des colonies portu. gaises d'.Afrique, pt. 2, Nouvelles données sur la zone littorale d'Angola, p. 44, pl. 1, figs. 4, 5, Lisbon, 1905.

10 Schlagintweit, Otto, Die fauna des Vracon und Cenoman in Peru: Neues Jahrb., Beilage-Band 33, p. 109, 1911.

' 20 Woods, Henry, The paleontology of the Upper Cretaceous despoits of northern Nigeria, in Falconer, J. D., The geology and geography of northern Nigeria, appendix 2, p. 277, pl. 20, figs. 1-3, London, 1911.

"Pervinquière, Léon, Études de paléontologie tunisienne, pt. 2, Gastropodes et lamellibranches des terrains crétacés, p. 174, pl. 13, flgs. 4, 5, 9, Paris, 1912.

21 Böse, Emil, On a new ammonite fauna of the lower Turonian of Mexico: Texas Univ. Bull. 1856, p. 230, pl. 20, fig. 4, 1918. 
It appears to the writer, after examination of the many published figures and of the specimens noted below, that there is no really essential difference between $E$. oxyntas and E. olisiponensis and that they may be considered one species with variable sculpture. $E$. olisiponensis may then be thought of as including a series of forms ranging in radial sculpture of the left valve from nearly smooth forms through forms with discontinuous irregular ribs to forms with strong widely spaced ribs and forms with closer-set weaker ribs. The ribs are always narrow and the interspaces relatively wide, concave. In concentric sculpture it ranges from nearly smooth forms to forms with conspicuous lamellae raised into high spinose flutings. In size it is usually 50 to 80 millimeters in maximum dimension, though it may reach 165 millimeters. In form it varies less than in sculpture: The outline is usually oval to subcircular; the upper valve is nearly flat; the lower valve is gibbous, regularly rounded. The degree of coiling varies, being dependent on the size of the area of attachment. In large collections all the extreme variants are connected by series of intermediate forms, and no chronologic value appears to attach to individual variants.

Pervinquière's grouping of the variants is perhaps as good as any:

1. Typical form. Upper valve with central part ribless; lower valve with ribs distant, discontinuous, rising into spines.

2. Nar. oxyntas Coquand. Lower valve with ribs relatively fine, numerous, continuous, not spinose.

3. Var. duplex Paulcke. Upper valve with strong radial ribs reaching almost to the nucleus of the shell; lower valve with strong, distant, spinose ribs and with a deep sulcus on posterior side bordered by high ribs.

4. Var. unnamed (=cornuarietis Meneghini, not Goldfuss). Lower valve ribbed on only third or half of shell nearest the beak, remainder nearly smooth.

5. Var. unnamed (=pseudoafricana Coquand, part). Lower valve nearly smooth or lamellose; ribs very few or weak.

6. Var. unnamed (=trigeri Coquand of Peron). Lower valve with lamellae only, raised here and there in flutings; no ribs.

From southern Utah the writer has some 19 specimens assignable to $E$. olisiponensis. To these may be added that figured by C. A. White ${ }^{23}$ as E. ponderosa Roemer. Sixteen of the specimens came from a locality 2 miles northeast of Notom, Wayne County, Utah, on the road from Notom to Caineville, collected in part by E. M. Spieker and the writer, in part by the late Robert Forrester, of Salt Lake City (U. S. Geol. Survey localities. 6942 and 12248). Eight of these specimens are right valves and eight are left valves. A single large specimen was collected by H. B. Waters at a locality 2 miles west of Escalante, Garfield County (U. S. Geol. Survey locality 10401). Two other large specimens were collected years ago in southern Utah by members of the Powell Survey

${ }^{23}$ White, C. A., Report upon the invertebrate fossils collected in portions of Nevada, Utah, Colorado, New Mexico, and Arizona: U. S. Geog. Surveys W. 100th Mer. Rept., vol. 4, pt. 1, p. 172, pl. 14, figs. 1 arc, 1875. of Colorado River. One of these is marked "Black Bluff," but the second is unlabeled. White's figured specimen came from Impracticable Ridge.

For comparison the writer has three specimens from Colombia collected by Dr. M. A. Rollot; half a dozen specimens from eastern Ecuador collected by J. H. Sinclair and Theron Wasson; and three specimens. from Angola collected by C. W. Washburne. Chief dependence was necessarily placed on published figures.

The stratigraphic position of the collection from the locality 2 miles northeast of Notom is at the base of the Mancos shale. The only fossil directly associated. with E. olisiponensis here is Gryphaea newberryi Stanton, which occurs in great abundance, though one of the valves of E. olisiponensis was attached to a shell of Plicatula hydrotheca White and bears a fairly clear mold of it. Over a large area in Utah, Colorado, and New Mexico Gryphaea newberryi marks a zone in which occur lower Turonian species such as Metoicoceras whitei Hyatt, and there is every reason to believe that the age at the locality near Notom is the same. The locality 2 miles west of Escalante is near the base of the beds of Colorado age, a horizon definitely lower Turonian. The specimen from Black Bluff grew upon a shell of Anchura? forresteri Reeside ${ }^{24}$ closely alin to $A$. olisiponensis Choffat, assigned to the lower Turonian.

The following notes on the specimens from Utah will be of service:

Right valves unassigned to varieties (pl. 65, figs. 1-7; pl. 66, fig. 3).-These are very close to various figured right valves. They do not show the ribs extending as close to the nucleus as in Paulcke's specimen, ${ }^{25}$ but are much like those figured by Choffat ${ }^{26}$ and Peron. ${ }^{27}$

Typical variety (pl. 65, figs. 8-11; pl. 66, figs. 1-2).Some of the specimens from Utah fit very well Sharpe's figure. $^{28}$ They also resemble closely the specimens figured by Choffat ${ }^{29}$ and by Peron, ${ }^{30}$ though the ribs on the latter are nearly continuous. The forms figured by Woods ${ }^{31}$ and Fourtau ${ }^{32}$ are closest perhaps to the forms here considered typical though having fewer and weaker ribs and inclining toward the ribless variants. Böse's specimen ${ }^{33}$ seems to be closest to those placed here.

Variety duplex Paulcke (pl. 66, figs. 4-11).-One specimen from Utah (pl. 66, figs. 6-8) is very close to Paulcke's type. ${ }^{34}$ A second (pl. 66, figs. 4, 5) has

a Reeside, J. B., jr., Five new species of Cretaceous mollusks from Colorado and Utah: Washington Acad. Sci. Jour., vol. 18, pp. 1928.

os Paulcke, Wilhelm, op. cit., pl. 15, fig. 8.

26 Choffat, Paul, Faune crétacique du Portugai, vol. 1, ser. 4, Ostreidae, pl. 6, fig. $17 \mathrm{~b}, 1902$; Contributions à la connaissance géologique des colonies portugaises d'Afrique, pt. 2, Nouvelles données sur la zone littorale d'Angola, pt. 1, fig. 5, 1903. 27 Peron, Alphonse, op. cit., pl. 23, fig. 15.

${ }^{28}$ Sharpe, Daniel, op. cit., pl. 19, fig. 1.

${ }^{20}$ Choffat, Paul, Faune crétacique du Portugal, vol. 1, ser. 4, Ostreidae, pl. 6, fig. $17 \mathrm{a}, 1902$.

${ }_{30}$ Peron, Alphonse, op. cit., pl. 23, fig. 16.

31 Woods, Henry, op. cit., pl. 20, figs. 1-3.

32 Fourtau, R., op. cit., fig. 5.

${ }^{33}$ Böse, Emil, op. cit., pl. 20, fig. 4.

${ }_{84}$ Paulcke, Wilhelm, op. cit., pl. 15, figs. 7-8. 
weaker ribs. Choffat's specimen from Angola ${ }^{35}$ is very like those from Utah. A fine specimen of the variety duplex from Colombia, collected by Dr. M. A. Rollot, of Bogotá, is figured for comparison (pl. 66, figs. 9-11). It is a little stronger in sculpture than those from Utah but otherwise is much like them.

Variety oxyntas Coquand (pl. 67; pl. 68, figs. 1-2).The specimens from Utah referred to the variety oxyntas are not as finely and as evenly ribbed as those figured by Coquand ${ }^{36}$ and have more inclination toward a spinose ornamentation but are nevertheless close enough to be placed with them. A specimen figured by Lartet ${ }^{37}$ as $E$. overwegi var. scabra is much like those from Utah, as is also one figured by Peron. ${ }^{38}$ Two specimens from Angola are figured for comparison (pl. 68, figs. 1-2).

Variety forresteri Reeside, n. var. (pl. 68, figs. 3-5; p]. 69, figs. 1-4).-Several large shells from southern Utah, one preserving both valves, seem to differ enough to deserve a new varietal name. The right valve shows an umbonal smooth area bordered by a zone of fine radial striations; the remainder of the surface shows concentric lamellae interrupted by areas of indistinct fine radial striation. The left valve has close-set regular ribs, like those of the variety oxyntas, in the umbonal region, but these pass into irregular flutings on the middle of the shell and the latest stages of growth show chiefly the concentric lamellae.

E. ponderosa White (not Roemer) ${ }^{39}$ belongs here (pl. 69, figs. 1-2). One of Coquand's figures of E. overwegi $(=\text { oxyntas })^{40}$ suggests the form also. Other comparisons with published figures might be made but seem of rather doubtful value.

\section{Exogyra costata Say}

Plate 69, Figures 5-8

1820. Exogyra costata Say, Am. Jour. Sci., vol. 2, p. 43.

1828. Exogyra costata Say. Morton, Acad. Nat. Sci. Philadelphia Jour., ser. 1, vol. 6, p. 85, pl. 6, figs. 1-4.

[For complete synonymy for years $1828-1926$ see Wade, U. S. Geol. Survey Prof. Paper 137, p. 56, 1926.]

? 1927. Exogyra cf. E. overwegi Von Buch. Trechmann, Geol. Mag., vol. 64, p. 53 .

Not 1871. Exogyra costata Say. Stoliczka, Palaeontologia indica, Cretaceous fauna of southern India, vol. 3 , p. 461, pl. 40, figs. 1-3; pl. 41, fig. 1 .

Exogyra costata Say has recently been described in great detail by Stephenson, ${ }^{41}$ and there is no need of

\footnotetext{
ss Choffat, Paul, Contributions a la connaissance gcologique des colonies portugaisos d' $\Lambda$ frique, pt. 2, Nouvelles données sur la zone littorale d'Angola, pl. 1, figs. $4-5,1003$.

${ }^{80}$ Coquand, Fenri, Monographie du genre Ostrea, terrain crétacé, pl. 44, figs. 1-7, 1860.

87 Lartot, Louis, op. cit., pl. 11, fig. 2.

ss Poron, Alphonso, op. cit., pl. 23, flg. 14.

80 White. C. A., op. cit., pl. 14, figs. 1 \&-c.

10 Coquand, Henri, Monographie du genre Ostrea, terrain crétacé, pl. 44, fig. 5, 1809.

"Steptionson, L. W., Species of Exogyra from the eastern Gulf region and the Carolinns: U. S. Geol. Survey Prof. Paper 81, pp. 50-53, pl. 16, figs. 3-4; pl. 17, figs. 1-2; pl. 18; pl. 19, flgs. 1-4; pl. 20, fig. 1, 1916; The Cretaceous formations of North Carolina: North Carolina Cleol. and Econ. Survey, vol. 5, pt. 1, pp. 173-179, pl. 47, flgs. 2-5; pl. 48, 1923.
}

repeating the discussion here. The species is characterized by attaining a large size; by the well-rounded form of the lower valve; by the sculpture of the lower valve-regularly arranged, simple or bifurcating, broad, flattened ribs separated by very narrow interspaces; by the sculpture of the upper valve-prominent concentric lamellae with rarely radial costae on the posterior portion.

To judge from scattered citations and figures in the literature $E$. overwegi Von Buch is of nearly the same age and very much like $E$. costata in form and sculpture. Whether it is identical can be decided only by comparison of authentic material of $E$. overwegi with $E$. costata. The identity of $E$. overwegi was for long obscured by confusion with $E$. olisiponensis Sharpe (see pp. 268-270), and only in later works has it been correctly interpreted.

The writer has in hand two mutually attached shells of E. costata collected by W. T. Lee in the SE. $1 / 4$ sec. 11, T. 6 . N., R. 69 W., about 5 miles south of Fort Collins, Colo., and just south of Fossil Creek. The horizon is in the sandstone constituting the exposures long known as Fossil Ridge, which has yielded a large fauna listed by Henderson. ${ }^{42}$ Stratigraphically the sandstone of Fossil Ridge is near the top of a series of five sandstones which in early work were interpreted as one and named the Hygiene sandstone. Later work by several geologists, especially those examining the region for oil companies, has shown the series to include an interval of some 1,500 feet. The five sandstones are now called, in ascending order, the Hygiene, Terry, Rocky Ridge, Larimer, and Richard sandstone members of the Pierre shale. ${ }^{43}$ The Rocky Ridge and Larimer sandstones make Fossil Ridge. The Milliken sandstone member of the Fox Hills sandstone, containing Sphenodiscus lenticularis Owen, lies 5,000 to 6,000 feet higher in the section than the sandstones of Fossil Ridge, and the Niobrara formation about 3,000 feet below them. The fossils reported from the sandstones of Fossil Ridge show that they are of upper Campanian age; these include such species as Baculites ovatus Say, Baculites compressus Say, Acanthoscaphites? nodosus Owen, Placenticeras intercalare Meek, and Ptychoceras sp. An element in the fauna of Fossil Ridge of great interest as joining with Exogyra costata in indicating a connection with that of the Gulf series consists of the species Capulus spangleri Henderson, Gyrodes abyssina (Morton), Gyrodes crenata (Conrad), Anchura haydeni White, and Volutoderma clatworthyi Henderson. In the Gulf series Exogyra costata is not usually associated with fauna containing the genus Placenticeras, its normal range being higher, but it does at some places so occur.

42 Henderson, Junius, The Cretaceous formations of northeastern Colorado: Colorado Geol. Survey Bull. 19, pp. 31-32, 1920.

13 Mather, K. F., Gilluly, James, and Lusk, R. D., Geology and oil and gas prospects of northeastern Colorado: U. S. Geol. Survey Bull. 796, pp. 65-124, 1928. 
PLATES 65-69

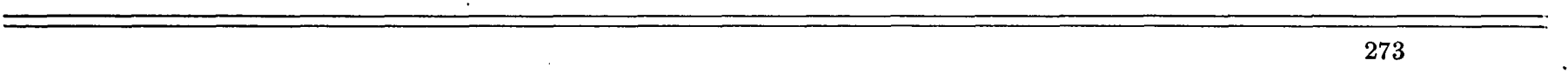


PLATE 65

Figdres 1-7. Exogyra olisiponensis Sharpe. Three right valves from the base of the Mancos shale on the road from Notom to Caineville, 2 miles northeast of Notom, Wayne County, Utah. U. S. Nat. Mus. catalogue No. 73613_8-11. Exogyra olisiponensis Sharpe, typical variety. Left valve from same locality. U. S. Nat. Mus. catalogue No. 73612 


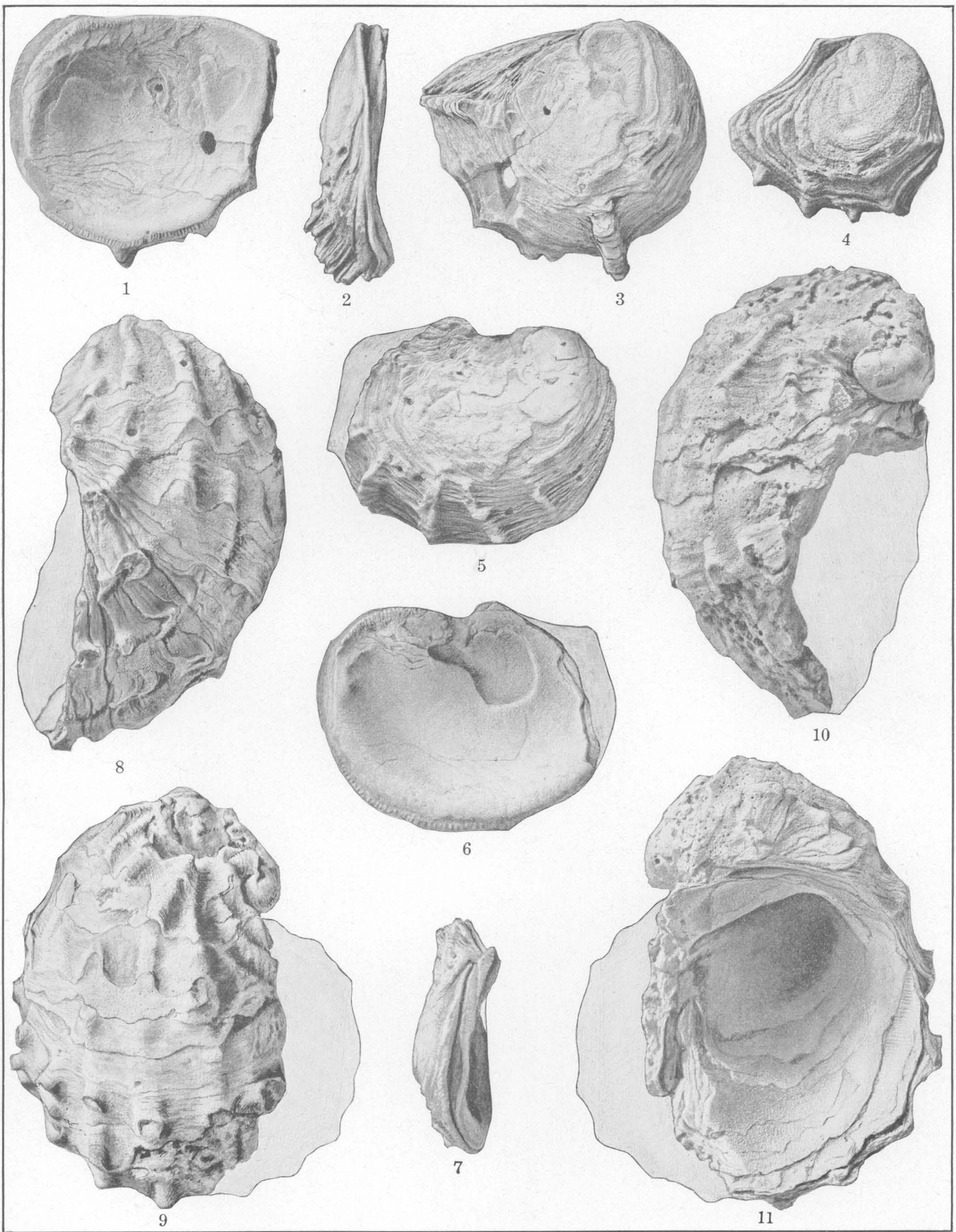

EXOGYRA OLISIPONENSIS SHARPE 


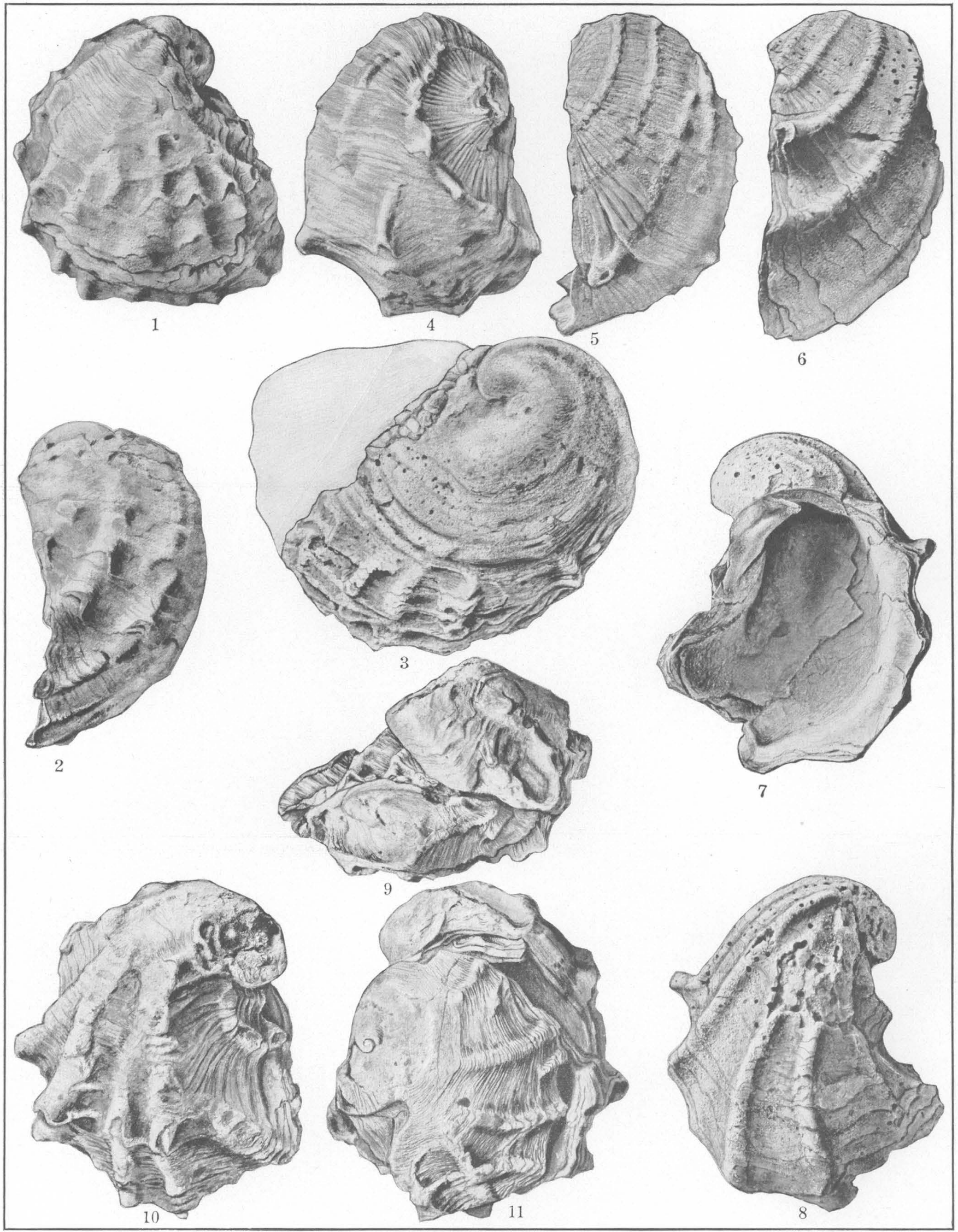

EXOGYRA OLISIPONENSIS SHARPE 


\section{PLATE 66}

Fradkes 1-2. Exogyra olisiponensis Sharpe, typical variety. Left valve from the base of the Mancos shale on the road from Notom to Caineville, 2 miles northeast of Notom, Wayne County, Utah. U. S. Nat. Mus. catalogue No. 73613

3. Exogyra olisiponensis Sharpe. Right valve from same locality. U. S. Nat. Mus. catalogue No. 73613.4-5. Exogyra olisiponensis Sharpe var. duplex Paulcke. Left valve from same locality. U. S. Nat. Mus. catalogue No. 73609

6-8. Exogyra olisiponensis Sharpe var. duplex Paulcke. Left valve from same locality. U. S. Nat. Mus. catalogue No. 73609

9-11. Exogyra olisiponensis Sharpe var. duplex Paulcke. Complete shell from Rio Villaviejo near La Union, Huila, Colombia, shown for comparison. U. S. Nat. Mus. catalogue No. 73607. 


\section{PLATE 67}

Frgeres 1-3. Exogyra olisiponensiz Sharpe var. oxyntas Coquand. Left valve from base of Mancos shale on road from Notom to Caineville, 2 miles northeast of Notom, Wayne County, Utah. U. S. Nat. Mus. catalogue No. $73610 \ldots$

4. Exogyra olisiponensis Sharpe var. oxyntas Coquand. Left valve from same locality. U. S. Nat. Mus. catalogue No. $73610 \ldots$

5-6. Exogyra olisiponensis Sharpe var. oxyntas Coquand. Complete shell, somewhat weathered, from locality 4 kilometers east of Novo Redondo, Angola, shown for comparison. U. S. Nat. Mus. catalogue No. 73604

7-8. Exogyra olisiponensis Sharpe var. oxyntas Coquand. Left valve from Black Bluff, Utah. U. S. Nat. Mus. catalogue No. $73611 \ldots$ 

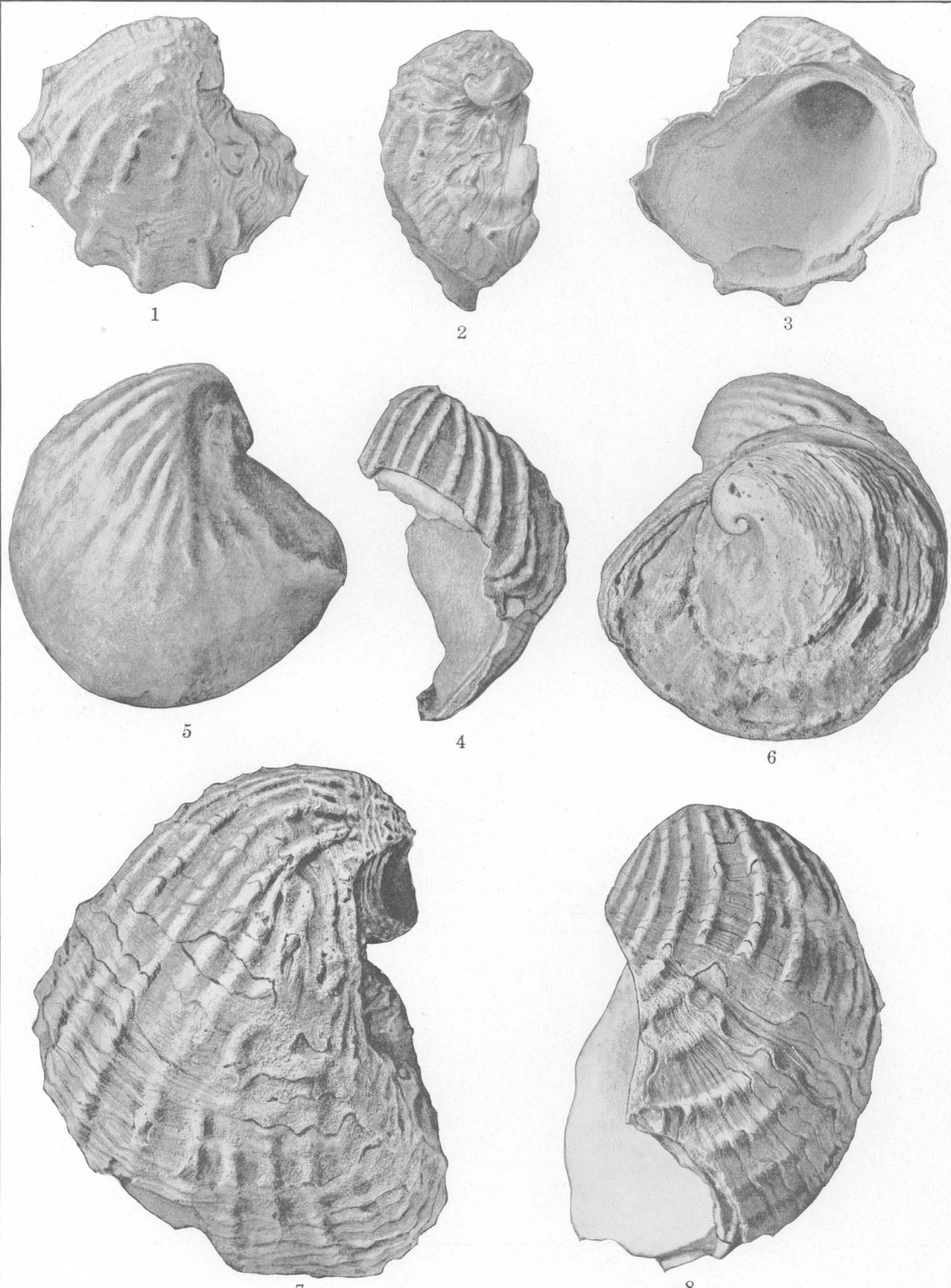

8

EXOGYRA OLISIPONENSIS SHARPE 


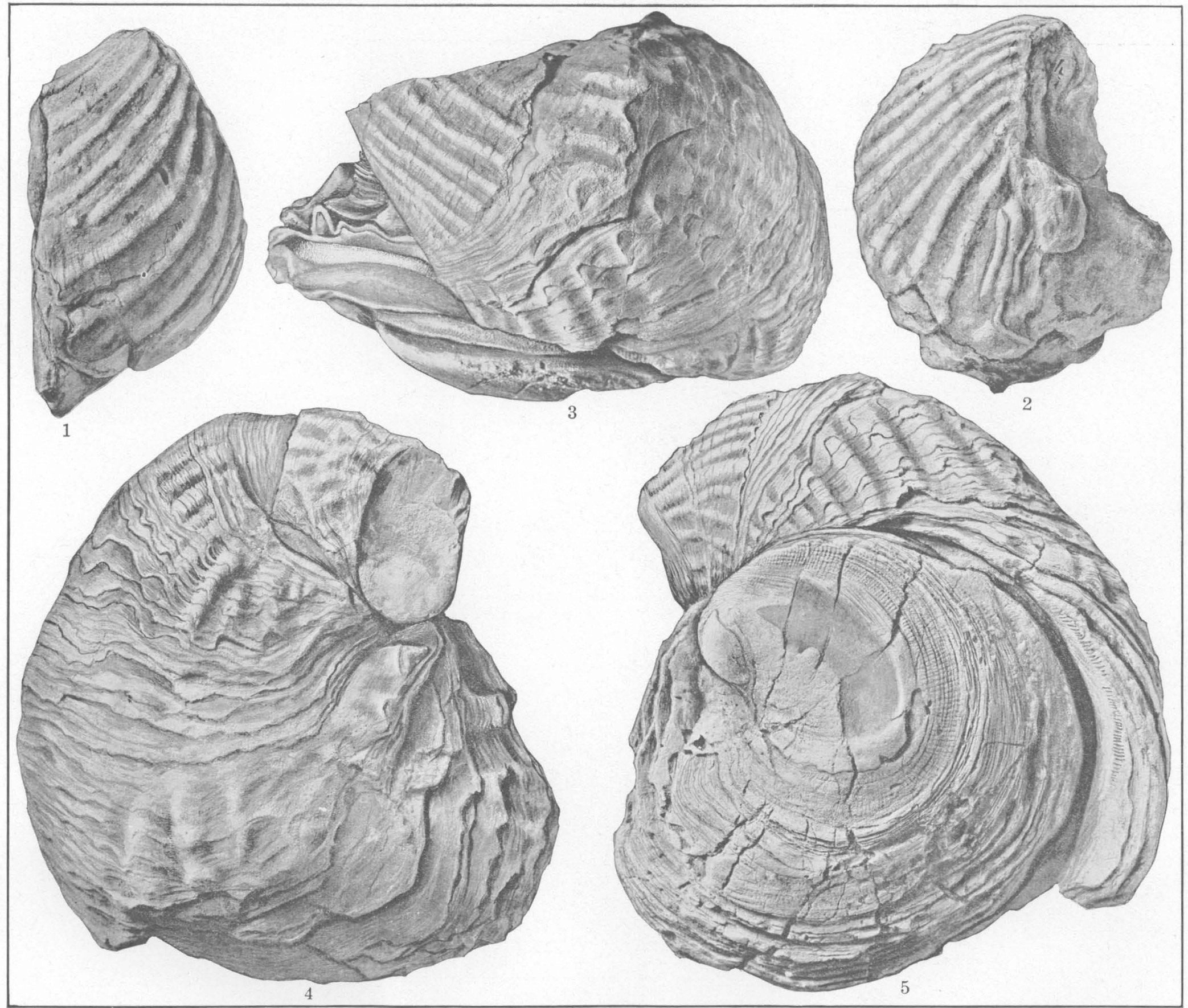

EXOGYRA OLISIPONENSIS SHARPE 


\section{PLATE 68}

Figures 1-2. Exogyra olisiponensis Sharpe var. oxyntas Coquand. Left valve from locality 4 kilometers east of Novo Redondo, Angola, shown for comparison. U. S. Nat. Mus. catalogue No. 73604 3-5. Exogyra olisiponensis Sharpe var. forresteri Reeside, n. var. Type specimen from base of beds of Colorado age, 2 miles west of Escalante, Garfield County, Utah. 'U. S. Nat. Mus. catalogue No. 73605 


\section{PLATE 69}

Figures 1-2. Exogyra olisiponensis Sharpe var. forresteri Reeside, n. var. Left valve figured by C. A. White as E. ponderosa Roemer. Impracticable Ridge, Utah. U. S. Nat. Mus. catalogue No. 13417

3-4. Exogyra olisiponensis Sharpe var. forresteri Reeside, n. var. Left valve from southern Utah, exact locality unknown. U. S. Nat. Mus. catalogue No. 73608

5-7. Exogyra costata Say. Two mutually attached shells from Fossil Ridge, 5 miles south of Fort Collins, Colo. U. S. Nat. Mus. catalogue No, 73606 


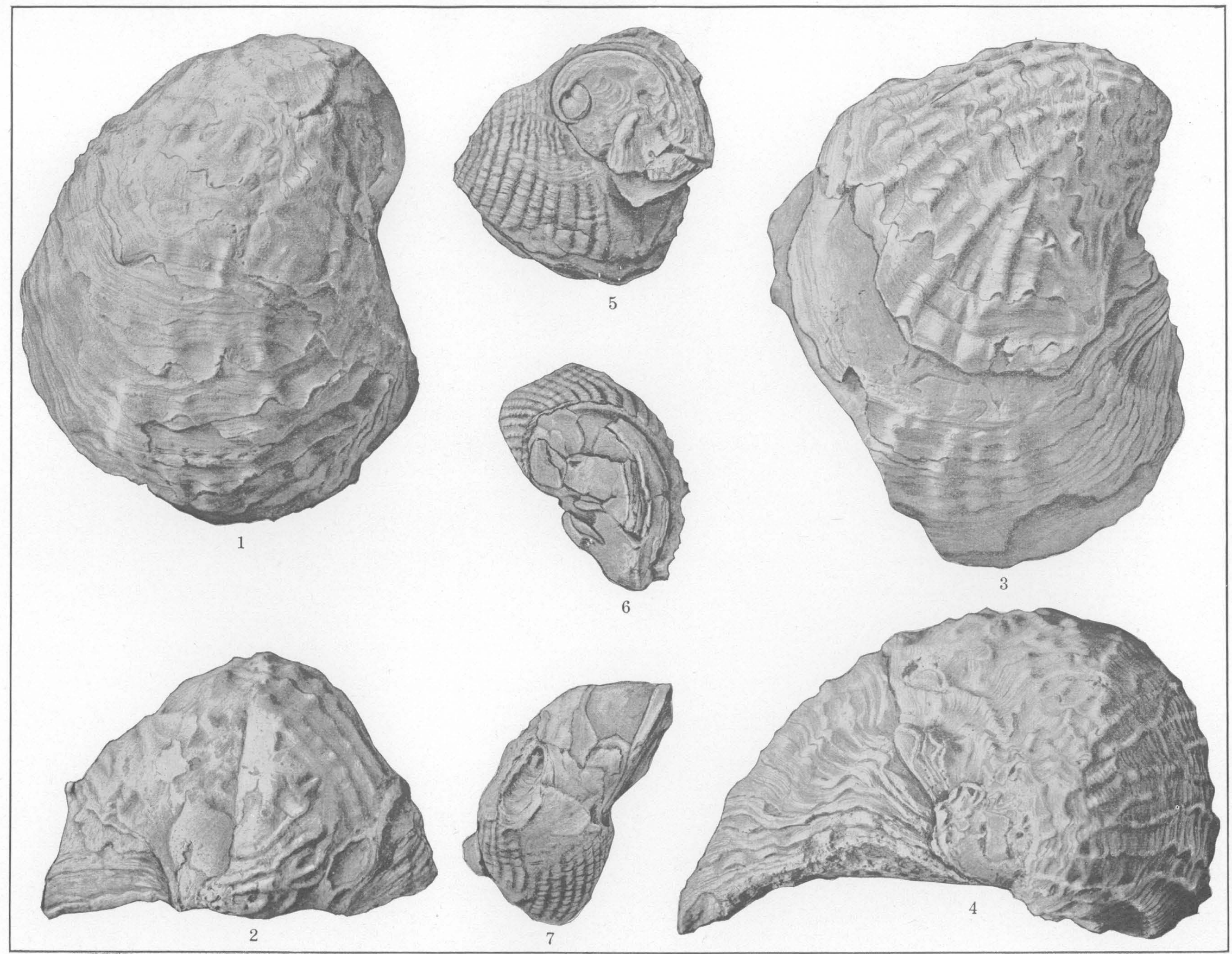

EXOGYRA OLISIPONENSIS SHARPE AND EXOGYRA COSTATA SAY 